\title{
A STORM DRIFTING BY? \\ DEFAMATION LAW AND SPORT IN \\ AUSTRALIA AND NEW ZEALAND
}

\author{
Chris Davies*
}

The law of defamation provides protection to people's reputations. An examination of the sportsrelated defamation cases in Australia and New Zealand indicates that such claims have been based on written comments, spoken words and also visual images. These cases can be internal comments made by those involved in a sport, as illustrated by the recent comments made by the coach of the Melbourne Storm, Craig Bellamy. However, as the recently decided case of Coates v Harbour Radio Pty Ltd indicates, most of the cases have involved comments made by people in the media rather than within the sport. An examination of defamation and sport, therefore, requires an examination of the sometimes delicate balance between the media's desire to report and comment on controversial sporting matters, and the desire of those involved in sport wishing to protect their reputations.

\section{INTRODUCTION}

The lead up to the 2008 National Rugby League (NRL) Grand Final featured extensive media attention, not just in regard to the match, but also in relation to the criticisms made the previous week by Melbourne Storm coach, Craig Bellamy, concerning the performance of the NRL's judiciary. Bellamy and the Melbourne Storm were immediately fined $\$ 50,000$ by the NRL, but this did not prevent members of the NRL judiciary from taking legal action. This is not the first time that the NRL judiciary has taken such defamation action: proceedings were taken against Phil Gould after similar criticisms. ${ }^{1}$ The President of the Australian Olympic Committee (AOC), John Coates, meanwhile, was awarded \$360,000 damages against radio announcer Alan Jones in regard to his criticisms of Coates' handling of the Sally Robbins affair at the 2004 Athens Olympic Games. ${ }^{2}$

* Dr Chris Davies, BSc BA LLB (JCU) PhD (Syd), Senior Lecturer, Faculty of Law, Business and the Creative Arts, James Cook University.

1 Hall v Gould [2002] NSWSC 359.

2 Coates v Harbour Radio Pty Ltd [2008] NSWSC 292. 
Such comments, however, are examples of the almost daily criticisms made by the media in relation to sport. This then raises the question as to when do such comments constitute valid criticism, and when do they constitute defamation? Visual images relating to sport are also published on a daily basis, either as part of news items on television, in papers or magazines, or as advertisements. Again this raises the question as to the circumstances under which such images become defamatory. Since New Zealand is now involved in trans-Tasman competitions with Australian teams in rugby league, rugby union, soccer, netball and basketball, it is also worth taking into consideration the law of defamation in both Australia and New Zealand when examining the question of defamation and sport.

This paper will therefore examine the law of defamation in regard to sport in Australia ${ }^{3}$ and New Zealand ${ }^{4}$ by examining the incidents involving the comments made by Bellamy, Gould and Jones as well as other known sport cases in Australia and New Zealand involving the print medium, spoken comments and visual images. What will also be discussed is the often delicate balance between the media's need to discuss controversial incidents in sport, and the law's need to protect people's reputation.

\section{SPORT, DEFAMATION AND THE SPOKEN WORD}

\section{A The Bellamy Case}

The incident involving Bellamy and Melbourne Storm arose after its captain, Cameron Smith, was suspended for two matches week for an illegal 'grapple' tackle in which a player deliberately puts his arm around the tackled player's throat. The result of this suspension was that Smith missed both the Preliminary Final and the Grand Final. During a press conference after the Storm's win in the Preliminary Final, and with Brian Waldron, the club's chief executive, beside him, Bellamy launched into an attack on the judiciary's decision to suspend Smith. His claims were that the

3 Note that uniform defamation Acts were adopted by the various Australian jurisdictions in 2006. In those states that had an earlier defamation Act, rather than actually repealing these earlier pieces of legislation, each new Act simply states that the general law in regard to defamation applies "as if those statutes has never been enacted". The relevant legislation in each state and territory in regard to defamation are now the Civil Law (Wrongs) Act 2002 (ACT); Defamation Act 2006 (NT); Defamation Act 2005 (NSW); Defamation Act 2005 (Qld); Defamation Act 2005 (SA); Defamation Act 2005 (Tas); Defamation Act 2005 (Vic); Defamation Act 2005 (WA). For further discussion see David Rolph "Uniform at Last? An Overview of Uniform, National Defamation Law" (2006) 76 Precedent 35.

4 Until 1954, defamation law in New Zealand was covered by the Libel Act 1792 (UK), the Law of Libel Amendment Act 1910 and the Law of Libel Amendment Act 1933. These three Acts were then expressly repealed by s 23 of the Defamation Act 1954. There were two subsequent amendments to the 1954 Act, the Defamation Amendment Act 1958 and the Defamation Amendment Act 1974 before the enactment of the Defamation Act 1992, schedule 3 of which repealed these 1954-74 Acts. 
judiciary had succumbed to the media hype surrounding the incident, and that the bookmakers had known of the result of the hearing before it had even been held. ${ }^{5}$

This verbal attack led to the NRL fining the club $\$ 50,000$ for attacking the judiciary's integrity, but this was not enough for the members of the judiciary panel, Darrell Williams, Royce Ayliffe and Darren Britt, who also called for an apology from Bellamy and the Melbourne Storm. The Panel also indicated legal action would commence if an apology was not forthcoming by the time of the NRL Grand Final. Bellamy refused to make an apology in the lead up to the Grand Final, ${ }^{6}$ though he and Waldron made a belated apology in the days following the match. Bellamy stated that he had not intended "to question the integrity or reputation of the members of the judiciary." 7 Despite the apology, members of the judiciary panel have commenced legal action in the NSW Supreme Court. $^{8}$ On the first day of proceedings Bellamy and Waldron repeated the apology but this was not accepted by the members of the judiciary panel and they are continuing with the action. ${ }^{9}$

The incident clearly indicates a judiciary body, such as the NRL's, will draw a line at what it will accept as fair criticism of its decisions. However, it also illustrates that an immediate and genuine apology would have satisfied the panel. This perhaps reflects that, as former first grade players, they all understood the culture of sport and that the passion it can generate can lead to comments being made in the heat of the moment which are later regretted by the makers. The case involving Bellamy, however, is not the first time that NRL judiciary have taken legal proceedings as comments made by Phil Gould, a well known former rugby league player and coach now involved in the media, were also the subject of court action.

\section{B Hall v Gould}

Spoken criticisms were made by Gould during the 2GB radio broadcast which aired on 16 August, 2001. The imputations pleaded in regard to the 2GB broadcast were that the Panel had acted perversely in finding Smith guilty in striking another player; that they had acted corruptly in finding Smith guilty; and that the Panel acted so unfairly that other players cannot expect to get a fair

5 S Honeysett and M Pelly "Bellamy's Sorry State of Affairs" (8 October 2008) The Australian 22.

$6 \quad$ S Honeysett and D Koch "Bellamy a Step Closer to Litigation" (2 October 2008) The Australian 18.

7 Honeysett and Pelly, above n 5, 22.

8 A Webster "NRL punts judiciary" (6 March 2009) The Daily Telegraph Sydney. Note that the NRL then suspended the three judicial members replacing them with Paul Conlon, Brad Clyde and Sean Garlick. It should be further noted that one of the changes made to the uniform defamation Acts was the introduction of clear guidelines as to which jurisdiction the matter should be heard in. If the publication has been in a more than one jurisdiction it is in the jurisdiction in which the harm caused by the publication has its closest connection, with one consideration being where the plaintiffs reside which in this case was New South Wales: see Defamation Act 2005, s 11 (NSW).

9 A Proszenko "Apology by Storm Pair Cuts no Ice with Judiciary Trio" (3 May 2009) The Sun-Herald Sydney, 91. 
hearing. ${ }^{10}$ In relation to the use of the word perversely, Levine $\mathrm{J}$ stated that "the context can be referred to in order to reinforce the available lay meaning of an ordinary English word". ${ }^{11}$ In regard to capacity, his Honour stated that as a matter of law the statement was capable of carrying this meaning, and that the tenor of the broadcast was such that it easily led itself to the availability of such a meaning. ${ }^{12}$ It was therefore capable of being defamatory. ${ }^{13}$

The second imputation involving the use of the word "corruptly" and asserted that Ayliffe, Roberts and Williams "did not bring their own minds to bear on the matter, but blithely accepted the mere opinion of the Commissioner". ${ }^{14}$ This matter complained off was capable of carrying this imputation and was capable of being defamatory. ${ }^{15}$ The third imputation from the radio broadcast was challenged on the basis of capacity in the sense that a published matter referring "to misconduct on one occasion is incapable of making a general charge of the same misconduct", with Levine J stating that this imputation was framed as a general charge. ${ }^{16}$ His Honour then held that the closing remarks where Gould had stated he had "been very critical of the Judiciary over the last 18 months", ${ }^{17}$ supported the availability of this imputation. This was held to be capable of being carried, and capable of being defamatory. ${ }^{18}$

Although the matter was settled out of court without the matter going to a jury, ${ }^{19}$ Justice Levine's decision indicates that comments made on the radio by someone working in the media about those carrying out official duties within a sport can be capable of being defamatory. It is also suggested that in the Bellamy case a similar conclusion may well be reached as the comments could be considered to lower the reputation of the members of the judiciary. Comments made on a radio programme concerning the performance of an official were also the issue in Coates $v$ Harbour Radio Pty Ltd.

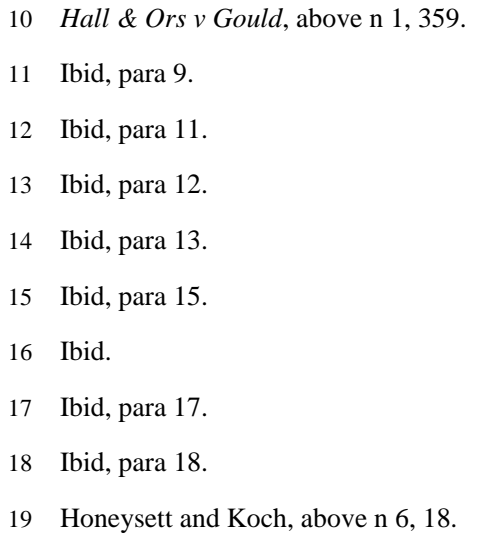




\section{Coates v Harbour Radio Pty Ltd}

\section{Background}

Sally Robbins was selected for the Australian Women's Eights that made the final at 2004 Athens Olympics, ${ }^{20}$ but about half way through the race Sally Robbins stopped rowing and lay down in the boat. When the team returned to the official finish area comments were then made in the presence of the media, including one likely to have been made by one of the crew which was "Tell the truth, Sally."21

Coates had watched the race on television and had seen Robbins collapse in the boat, and a short time later had answered questions with the media. A question was put to him by a reporter that it was "un-Australian" to criticise your team mates and Coates had replied, "Yes, it is un-Australian to bag your mates". ${ }^{22}$ This was later broadcasted on Channel Seven. ${ }^{23}$ One of the other members of the crew, Kyeema Doyle, later gave an interview with the Australian Broadcasting Commission (ABC) on the morning of 23 August in which she defended the criticisms made by the crew in the aftermath of the race. This was in breach of the Olympic team rules regarding talking to the media, and as a consequence Coates told Peter Huggett, the Assistant Team Manager for rowing, to tell the team to remain in the Olympic village. ${ }^{24}$

One of the members of the crew, Karen Foulkes, then decided that the team needed help and left a message on Coates' phone to that effect, though he did not respond as he was busy at the time and also because he knew that a team meeting had been scheduled for 7.30am the following day. ${ }^{25}$ Another crew member and the captain of the women's rowing team, Vicki Roberts, contacted one of the athlete liaison officers, John Eales, a former Australian rugby union captain. Eales agreed to have a meeting at $10.00 \mathrm{pm}$ that evening and also rang Coates to inform him of this. ${ }^{26}$ At the meeting with Roberts, Foulkes and Wilson, the crew members indicated they wished to move forward from the situation, with Eales suggesting that he would speak to Robbins. They agreed, and Eales then spoke to Robbins who acknowledged that the other three women wanted an explanation

\footnotetext{
20 Coates $v$ Harbour Radio Pty Ltd, above n 2, 292

21 Ibid, para 22.

22 Ibid, para 43.

23 Ibid, para 45.

24 Ibid, para 51.

25 Ibid, para 61.

26 Ibid, para 64.
} 
of what had happened. ${ }^{27}$ It was agreed that such a meeting needed to be with the whole team and that a public statement also needed to be made. ${ }^{28}$

The following morning, 24 August, Eales met with the whole team with Robbins giving the team an explanation as to what had happened. While several members of the crew expressed their feelings about what had happened, Eales stated in evidence that he could not recall any criticisms being made of Robbins. It was also agreed that Robbins and a few other team members needed to speak to the press. ${ }^{29}$ The team then met with Coates, who apologised for his un-Australian comment, ${ }^{30}$ and a press conference was arranged for later that day. Robbins acknowledged to the press that she had had similar problems in other races prior to the Olympic Games and was seeing a sports psychologist about what appeared to be mental weaknesses that affected her in big races. ${ }^{31}$

It was these events that lead to the comments at the centre of Coates $v$ Harbour Radio Pty Ltd, namely those made by Jones during his early morning radio programme some three and half months later. The first occurred at 5.55am on 8 December, 2004, during a conversation with Andrew Moore. Jones stated that the story raised "significant questions ... over the leadership of the Australian Olympic movement" and that "they practiced a cover up from the moment something happened to Sally Robbins and the leadership of the Olympic movement, Coates and others, virtually were telling these people what to say." He went on to say that "the leadership here was sadly lacking in how to handle this", and that Coates had been in charge of too many Olympic committees and it was "time to give someone else a go". ${ }^{32}$ Later that morning at 8.07am Jones made further comments, claiming that parents of Australia's rowers had accused the sporting officials of ordering a cover up and that the AOC had told the crew what to say at the news conferences. He further stated that this "has been badly handled" and that there were many saying that "it really is time for John Coates to give the guernsey to someone else."33 On the following morning, Jones made further statements that "it was the Olympic leadership that were at fault", that Coates "has been there too long and something needs to be done", and that the "handling of the whole business was awful". 34

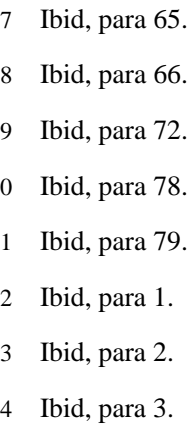


The imputations that arose from these broadcasts were that Coates had ordered a cover-up, that his leadership was lacking and incompetent at the relevant time, and that he had bullied the crew into saying what he wanted them to say at the news conferences. ${ }^{35}$ The defences of substantial truth, contextual truth and comment were then raised by Harbour Radio Pty Ltd and Jones. ${ }^{36}$

\section{Judgment of Adams $J$}

The first imputation addressed by Adams J was that Coates had practised or ordered a cover up over Robbins' collapse. ${ }^{37}$ His Honour defined cover up as being a term used where there is some duty, either legal or moral, to disclose certain facts and there is a refusal to disclose those facts and there is an attempt to deflect any enquiry. It therefore involves disguising as well as concealing the truth, though mere silence was not a cover up. ${ }^{38}$

The defendants' written and oral submissions had argued that information might be disclosed at a press conference which could be damaging or embarrassing to those who had been responsible for the selection of Robbins, namely Rowing Australia and the Australian Olympic Committee. However, it was noted by Adams $\mathrm{J}$ that Coates had played no part in the selection of the rowers for the 2004 Olympics as this was determined by the relevant sporting organisation, and it was not part of his responsibilities to satisfy himself as to the physical or mental capacity of anyone who was nominated for the Olympic team. ${ }^{39}$ There was nothing, therefore, in the selection criteria to embarrass Rowing Australia, let alone the Australian Olympic Committee and its president. Coates had been made aware of the previous problems with Robbins finishing races on 23 August, "but this knowledge was incapable of giving rise even to a frisson of impropriety, let alone a scandal".40 Adams $\mathrm{J}$ then held that "the imputations suggestive of a cover-up were patently false [and] they could not survive even the most cursory examination of the team's press conference". ${ }^{41}$

The second imputation was that Coates had bullied the crew members into saying what he wanted them to say after the incident and at a news conference. ${ }^{42}$ Adams J noted that the "notion of bullying involves the misuse of a strength or power to coerce or suppress a weaker person". ${ }^{43}$ The

\footnotetext{
35 Ibid, para 4.

36 Ibid, para 5.

37 Ibid, para 94.

38 Ibid.

39 Ibid, para 11.

40 Ibid, para 98.

41 Ibid, para 109.

42 Ibid, para 110

43 Ibid, para 112.
} 
actual acts allegedly involving bullying were the requirement that the crew members return to the village on 23 August, the "un-Australian" comment, and a direction at the press conference that no criticism was to be made of another rower. ${ }^{44}$ Adams J, however, held that Coates' conduct did not amount to bullying as it lacked the element of oppression, and, to the contrary, the plaintiff had acted reasonably and appropriately. ${ }^{45}$ The requirement that the team return to the village was "a reasonable and sensible response to the developing problem", ${ }^{46}$ and as Chef de Mission, he had the authority to take action that was appropriate for the good of the team. ${ }^{47}$ His Honour also held that it had been the team who had decided what should be said at the press conference, ${ }^{48}$ and therefore the suggestion that they were bullied into saying what was said at the conference was completely untrue. ${ }^{49}$ Adams $\mathrm{J}$ also held that the "un-Australian" comment did not involve bullying, as Coates was entitled to condemn any disparagement by one member of the team by another. While his Honour stated that the choice of strong language was unwise in the situation, he pointed out that Coates had apologised at the earliest opportunity. ${ }^{50}$

The third imputation was that Coates' leadership was sadly lacking and incompetent in dealing with the Robbins affair. ${ }^{51}$ In deciding on this matter Adams $\mathrm{J}$ referred to a report made by head rowing coach, Harold Jahrling, and noted that by the time Robbins' name had come to the AOC, the issues surrounding her competence had already been determined by Rowing Australia, and "it was not for the Australian Olympic Committee to second guess Rowing Australia in this respect". ${ }^{52}$ The selection process, therefore, formed no part of Coates' management or leadership of the Australian Olympic Committee, nor did it demonstrate any incompetence in his dealing with the incident, or the way he handled the Robbins affair. ${ }^{53}$ Any reference to team management was to that of Rowing Australia for which Coates was not responsible. ${ }^{54}$

\footnotetext{
44 Ibid.

45 Ibid, para 113.

46 Ibid, para 114.

47 Ibid, para 116.

48 Ibid, para 118.

49 Ibid, para 119.

50 Ibid, para 121.

$51 \quad$ Ibid, para 123.

52 Ibid, para 126.

53 Ibid, para 130.

54 Ibid.
} 
Another fact relied on by Harbour Radio was that Coates did not meet or talk to the crew members until 24 August. Adams J held, however, that the only opportunity to meet the team was on the evening of the race, namely the 22 August, but it was obvious that this was not an occasion when such a consultation was appropriate. As it had not been shown that there was another appropriate time for a meeting, there was no basis for criticising Coates' management or leadership for not meeting with the crew before the morning of 24 August. $^{55}$

The final matter to deal with was the "un-Australian" comment, with his Honour stating that the context of its use was in regard to the fact that it was the wrong thing for one team member to criticise another. Coates had also admitted himself that it was not a remark that he should have made as a manager and a leader. ${ }^{56}$ Adams $\mathrm{J}$ then held that it was a momentary lapse and could not be seriously regarded as reflecting on Coates' leadership or management when the crisis was considered as a whole. ${ }^{57}$

As Harbour Radio had not established the truth of the imputations, it was then a question as to whether the imputations amounted to comment relating to a matter of public interest, a statutory defence under the relevant act, the Defamation Act 1974 (NSW). Adams J noted that a comment will only be defensible if it can be clearly identified apart from any matters of fact upon which it might be based, and that these facts must be sufficiently indicated at the time of the publication of the matter complained of. ${ }^{58}$ While it can be difficult to distinguish an allegation of fact from an expression of an opinion or comment, the later enables a reader to judge for themselves whether the opinion is well founded. ${ }^{59}$ In relation to the present case, his Honour noted that a radio listener does not have the time to re-read material and is therefore hindered in making even a cursory analysis in an attempt to distinguish between comment and fact. If the facts and comments are so mixed up that a listener cannot distinguish them, then the imputation will be indefensible. ${ }^{60}$

It had been submitted by Harbour Radio that the imputation in the first broadcast about the cover up was a statement of opinion, since it was a conclusion based upon what had happened at the press conference. Adams J disagreed, stating that this "was not how a reasonable listener would

55 Ibid, para 136

56 Ibid, para 145

57 Ibid, para 146

58 Ibid, para 150

59 Ibid, para 153. Justice Adams was referring to a quote by Lord Porter in Kemsley v Foot [1955] AC 345, 356-357 in which his Lordship was referring to a passage from W Blake Odgers A Digest of the Law of Libel and Slander (6ed, Stevens \& Sons Ltd, London, 1929) 166.

60 Ibid, para 154. 
have understood what was being said". 61 In regard to the imputation in the second broadcast, Adams J held that: ${ }^{62}$

The listener would have understood Jones to be saying that, as a matter of fact, the conference was the result of that order. The statement about the cover-up is not a comment at all. Jones was reporting, not commenting. His comment is that the plaintiff had to go ... this comment makes sense only on the basis that $\mathrm{Mr}$ Jones was of the view that the accusations made by and the concerns raised by the parents were true.

Adams $\mathrm{J}$ then addressed the bullying imputations, and held that the complaint that Coates had bullied the rowers into saying what he wanted them to say was a statement of fact, and not a comment, as "it was a description of the way that the instruction was communicated and how obedience to it was impelled". ${ }^{63}$ The second matter complained of in regard to the bullying imputation was that Coates had used his position as head of the AOC and Chef de Mission to bully the crew into saying what he wanted them to say. His Honour, however, held that this bullying imputation was a description of what Coates had done to the crew, not a comment on it. ${ }^{64}$

This then left the issue of the comments made in regard to the Coates' leadership and incompetence, with Harbour Radio submitting that it was a statement of opinion. Adams J held that the imputation attacking Coates' leadership "is an inference drawn from matters to which I have referred and therefore qualifies as comment. However, it is based on four matters, which if facts are either false or not shown to be true." 65 The statement that the Olympic leadership was at fault and that the handling of the whole business had been awful were held to be statement of facts that were not true. ${ }^{66}$ Under section 30(3) of the Defamation Act 1974 (NSW) the imputations had to be on proper material for comment, with the comments needing to be based on accurately stated facts. In relation to all three matters complained of Harbour Radio Adams J held that the facts did "not remotely form a proper basis for the comment" and that he did not think that a fair minded person "could have made such comments upon the basis of these facts, let alone reasonably". ${ }^{67}$ In relation to contextual truth his Honour stated that as not one of the imputations was substantially true, he did not have to consider the issue of contextual truth. ${ }^{68}$ Damages of $\$ 360,000$ were then awarded to

\footnotetext{
61 Ibid, para 156.

62 Ibid, para 158.

63 Ibid, para 159

64 Ibid, para 160.

65 Ibid, para 162.

66 Ibid, para 164.

67 Ibid, para 170.

68 Ibid, para 185.
} 
Coates, $\$ 130,000$ for both the bullying and cover-up imputations, and $\$ 100,000$ for the incompetence imputations. ${ }^{69}$

Coates $v$ Harbour Radio Pty Ltd was decided under the relevant act at the time, namely the Defamation Act 1974 (NSW), but it is suggested that the decision would have been no different under the present act, the Defamation Act 2005 (NSW). Section 31(1)(c) of the 2005 Act provides a defence if the matter was an expression of opinion and based on proper material. It is suggested that Adam J's conclusion that the facts did not form a proper basis for comment would mean that this section of the 2005 Act would not provide a defence to what was said in Coates $v$ Harbour Radio Pty Ltd. In New Zealand meanwhile, section 9 of the Defamation Act 1992 provides the defence of honest opinion which replaces the previous fair comment defence. Section 10(1) requires the opinion to be genuine. Section 11 then states that in respect of a matter consisting partly of statements of fact and partly statements of opinion, the truth of every statement of fact does not have to be proved, if the opinion is shown to be genuine having regard to those facts alleged in the publication which are proven to be true. It is suggested that Adams $\mathrm{J}$ conclusion in regard to the facts would mean that this defence would not be successful if the matter had been heard under the Defamation Act 1992.

The New Zealand case of Anderson v Ginn ${ }^{70}$ meanwhile involved spoken comments made directly to others, rather than through the medium of radio or television. It was also a different situation in that it involved comments made by one member of a sporting committee about another member, rather than being made by an external party, namely the media.

\section{Anderson v Ginn}

John Anderson had been a member of the Wanganui East Tennis Club since it had been formed in the early 1920s. He was on the club's management committee and also the grounds committee and was essentially the honorary caretaker for the club.

On the 3 October, 1932, he went to the tennis courts to do some work there. ${ }^{71}$ The defendant's thirteen year old daughter was there at the time, and when she went home, she complained that she had been molested by Anderson. Ginn immediately went round and confronted Anderson just outside the tennis courts, threatening to call the police if Anderson ever set foot on the tennis courts again. During the conversation Ginn struck Anderson and refused Anderson's request to hear his side of the story. A little later that evening Anderson had visited Ginn's house, but Ginn had refused to talk to him and had slammed the door on him. Anderson then asked his son in law, Burston, to go round to try and talk to Ginn which was when the statement Anderson claimed to be defamatory was

69 Ibid, para 201.

70 Anderson v Ginn (No 2) [1933] NZLR 1073 (SC).

71 Ibid, 1076. 
made. ${ }^{72}$ The following morning Ginn met with the chairman of the management committee, $\mathrm{Mr}$ Walpole, and made statements concerning the incident, before stating that if Anderson kept away from the tennis courts then that would be the end of the matter. ${ }^{73}$ When Anderson commenced legal action there were three causes of action, namely the slander ${ }^{74}$ published to Burston, the slander published to Walpole, and the assault. ${ }^{75}$

In regard to the assault action, the jury awarded $£ 5$ in damages. Twenty pounds were then awarded for the slander to Burston, and $£ 75$ for the slander to Walpole. ${ }^{76}$ It was then a question of law as to whether the occasions on which the communications had been made to Burston and Walpole were covered by privilege. ${ }^{77}$

Myers CJ stated in regard to the statement made to Burston that, if Burston had been sent round as a general agent to discuss the matter on behalf of Anderson, then Ginn would have been justified in publishing the words that were complained of in explaining his own position. His Honour, however, held that Burston had not been sent as a general agent, but with a limited mandate from Anderson to request a personal interview with Ginn so that he could state his view of the incident. ${ }^{78}$ The object of Burston's visit had been made plain to Ginn who had stated that he was not prepared to discuss the matter with Anderson, before choosing "to volunteer a statement from which from his own evidence was clearly unnecessary." ${ }^{79}$ Myers CJ then held that there was no privilege in respect of the publication to Burston. ${ }^{80}$

In regard to privilege in relation to the statement made to Walpole, Myers CJ stated that: ${ }^{81}$

A privileged occasion is, in reference to qualified privilege, an occasion where the person who makes a communication has an interest or a duty, legal, social or moral, to make it to the person to whom it is

72 Ibid, 1077.

73 Ibid, 1079 .

74 Under the common law and some of the early defamation legislation slander involved non-permanent defamatory statements in spoken words or other transitory forms such as gestures while libel involved defamatory material in a permanent form, such as print or writing. Under the present legislation in Australia and New Zealand, both are now covered by the general tort of defamation: see for example Defamation Act 1992, s 7.

75 Anderson v Ginn, above n 70, 1074.

76 Ibid.

77 Ibid, 1076.

78 Ibid, 1078.

79 Ibid, 1079.

80 Ibid.

81 Ibid, 1080, quoting Adam v Ward [1917] AC 334 (Lord Atkinson). 
made, and the person to whom it is so made has a corresponding interest or duty to receive it. This

reciprocity is essential.

In regard to the case at hand, Myers CJ stated that if the girl had been molested, then Anderson would not have been a fit and proper person to be around the tennis courts, to continue as caretaker, or to remain a member of the club's grounds committee. His Honour then held that Ginn "had a moral or social duty (if not an interest) to make his communication to the proper authority in the club, and that that authority has a corresponding interest and duty to receive the communication." 82 This occasion was therefore held to be privileged by Myers CJ, and the finding for damages on that particular cause of action did not stand. ${ }^{83}$

It suggested that this decision, if heard today, would be decided no differently under the Defamation Act 1992 with the comments made to the management committee still covered by qualified privilege under section 16(3) which retains the common law in regard to qualified privilege. It is also the type of scenario that could be covered by the Children, Young Persons and their Families Act 1989, section 15 of which states that any person who believes a child has been sexually harmed may report the matter to a social worker or member the police, and under section 16 there can be no defamation action as long as such reporting was made in good faith.

\section{E Valid Comment or Defamatory Statement?}

A question that arises from these three cases is when are oral statements valid comments, and when do they constitute defamatory statements. The comments made by Jones were made without a first hand knowledge of the situation and he relied, in part, on what others had said happened, that is, it involved hearsay evidence. Advice that needs to be given to those in the media therefore is to check the facts before making such criticisms. Gould, on the other hand, can claim to have had a knowledge and understanding of the situation, but clearly went too far with his comments, using unnecessarily excessive language, rather than words that conveyed a more constructive criticism. Thus, the two cases illustrate that media criticisms of officials in high profile positions within sport can constitute defamatory imputations if they are not in fact true, or involve excessive language.

The situation in Anderson v Ginn involves another potential scenario, namely comments made by one committee member to another. Another difference to both Coates $v$ Harbour Radio Pty Ltd and Hall $v$ Gould is that it involved officials at a club level, not a national or international one. While it is a 1930s case, the facts are highly relevant to the present day since the protection of children involved in sport is now required by legislation. The case of Carter $v$ NSW Netball Association, ${ }^{84}$ also illustrates that allegations of abuse of children in sport can result in a denial of

82 Ibid, 1081.

83 Ibid, 1082.

84 Carter v NSW Netball Association [2004] NSWSC 737. 
procedural fairness, with the matter also being potentially defamatory. This case involved Sandra Carter who had been coaching and administrating netball with the Mt Druitt Netball Association for twenty years. This did not prevent allegations of child abuse being made against her in 2003 which led her to being found guilty of harassment under the NSW Netball Association's Anti-harassment policy. Notice was then given to the Commission for Children and Young People which had stated Carter had been the subject of disciplinary hearings relating to child abuse, sexual misconduct or acts of violence in the course of employment. ${ }^{85}$ The court, however, held that there had been a denial of procedural fairness and natural justice with the decision being held to be invalid. ${ }^{86}$

Like Anderson, therefore, Carter had been denied the opportunity of being able to give her side of the events, in her case to a disciplinary hearing, in Anderson's to the father of the child he was alleged to have molested. In both cases therefore the allegations themselves were, for all intents and purposes, treated as being sufficient indications of their guilt. Like Carter, Anderson, had little choice but to take the matter to court in order to, at least to some degree, clear his name, as otherwise he would almost certainly have been shunned by the tennis club, one to which he had devoted so much of his time. It should also be noted that the comments ultimately proved very costly for Ginn, since he had to pay Anderson significant damages plus costs. An involvement in netball was likewise obviously a major part of Carter's life, but the decision of the Disciplinary Committee meant her name was entered onto the Commission's database, meaning she could not be employed in any position involving direct, unsupervised contact with children which included coaching. ${ }^{87}$ The next question is whether this situation could also provide the basis for a defamation claim as the decision meant she had been branded a child abuser in her own community, leading her to being likely shunned, even though what she had done was no more than "enthusiastic coaching." ${ }^{88}$ Qualified privilege would probably provide a defence to what is said to a disciplinary committee, but as Anderson v Ginn indicates, this would not extend to comments made to others. Therefore, if allegations of abuse of a child in sport are made, then those involved need to make sure that proper procedures are followed and that any alleged perpetrators have an opportunity to give their side of the story. Until such time as the matter has been properly heard, those making the allegations should not be making comments to others, otherwise they could well find themselves facing a possible defamation claim. Even under the Children, Young Persons and their Families Act 1989 such reporting needs to be in good faith and made to appropriate authorities, either a social worker or a police officer.

85 Ibid, para 57. Under s 39 of the Commission for Children and Young People Act 1998 (NSW) it is the duty of an employer to notify the Commission of the name and particulars of any employee against whom relevant employment proceedings had been completed by the employer. Ibid, para 132.

87 Ibid, para 104. Carter was forced to cease her employment due to the stress of the case: ibid para 5.

88 Ibid, para 106. 


\section{SPORT, DEFAMATION AND THE PRINTED MEDIUM}

Sport receives extensive coverage in the daily newspapers, which invariably have a distinct "sports section", and also in various magazines. This coverage in the print medium contains previews and reviews of various sporting matches, events and competitions, and will frequently involve criticisms of sportspeople and also those who run sport. It is perhaps inevitable, therefore, that some of this criticism becomes the centre of a defamation claim.

In Henderson $v$ Thompson ${ }^{89}$ the plaintiff was a leading New Zealand jockey who suffered serious head injuries, including a fractured skull, in a fall during a horse race on 16 March, 1929. Henderson nearly died from the injuries and after recovering was paralysed on the right side and had defective vision. He then applied to the Racing Conference for compensation from the Accident Fund and was awarded full compensation in 1930. Two years later, however, he requested a clearance so he could ride again in England, but this was refused by the Racing Conference. ${ }^{90} \mathrm{An}$ article then appeared in the New Zealand Referee which stated that he had been a very fine horseman, but that the Racing Conference had acted with medical advice in regard to his request and had taken "the only honourable course". ${ }^{91}$ The article also noted that a further fall could prove fatal and that he had received full compensation from the Accident Fund. Henderson then sued the paper for defamation, with the innuendos pleaded being that (a) he was unfit to follow his occupation; (b) that it would be dangerous if he were permitted to ride in a horse race again; and (c) that he was suffering from such a degree of physical incapacity as to render him unfit to safely ride in horse races. ${ }^{92}$

In regard to the first innuendo, Ostler $\mathrm{J}$ held that because the statement only referred to the fact that he should not be allowed to race again due to the serious injuries suffered in a fall, the statement was not defamatory. This was because "such a statement does not tend to expose the man to hatred, ridicule, or contempt of his fellow men, or diminish his reputation, or cause him to be shunned or avoided". ${ }^{93}$ His Honour further held that an imputation of unfitness will only be defamatory where the unfitness is shown to have arisen by reason of lack of skill, experience, honesty or industry on the part of the plaintiff. ${ }^{94}$

Ostler $\mathrm{J}$ then stated that although the words used in the other two innuendos were capable of the meanings alleged, that is, it would be dangerous to permit someone to ride again in a horse race due

89 Henderson $v$ Thompson [1934] NZLR 444 (SC).

90 Ibid, 450.

91 Ibid, 445.

92 Ibid, 448. Justice Ostler did note however that the third innuendo was merely a combination of the first two.

93 Ibid.

94 Ibid. 
to previous injuries, they were not defamatory. ${ }^{95}$ Another significant finding was that at the time of the article Henderson was not actually a jockey, since under the rules of horse racing no one could carry on the occupation of a jockey unless he was the holder of a licence that was granted annually by the Racing Conference. ${ }^{96}$ He had therefore ceased to be a jockey when he had applied for compensation and informed the Racing Conference that he wished to go into some other business. ${ }^{97}$ His Honour then held that the law of defamation was well established "that a person suing for slander in relation to his calling cannot succeed unless he is following that calling at the time the slander was published". ${ }^{98}$

Henderson $v$ Thompson was later referred to in the Australian case of Boyd $v$ Mirror Newspapers $L t d^{99}$ involving Australian rugby league player, Les Boyd. Boyd had begun his first grade career with the Western Suburbs club in the then New South Wales Rugby League competition, the forerunner of today's NRL. He reached the highest level of the game by being selected to play for Australia in 1978 and 1979, and in 1980 he transferred to the Manly-Warringah club. It was after a game for Manly that the Daily Mirror published an article that was critical of Boyd's fitness and physical appearance under the headline "Boyd is fat, slow and predictable."100 The article also stated that Boyd was not capable of playing in his position of second row. Boyd then sued Mirror Newspapers for defamation, pleading the following imputations: that he was so slow that he could not play in his position as a second row forward; that he was so fat as to appear ridiculous on a first grade football field; and that he had allowed his physical condition to degenerate so that he was a hopeless second rower. ${ }^{101}$

In regard to the first imputation Justice Hunt held there was nothing in the description of being fat and slow, even if the person was a first grade rugby league player, that would tend to make people shun or avoid him, nor was it capable of displaying him in a ridiculous light. To be defamatory at common law, the imputation must be personally disparaging of the plaintiff, and without some suggestion that there was blameworthiness on the part of Boyd, such an imputation could not be said to be disparaging. ${ }^{102}$

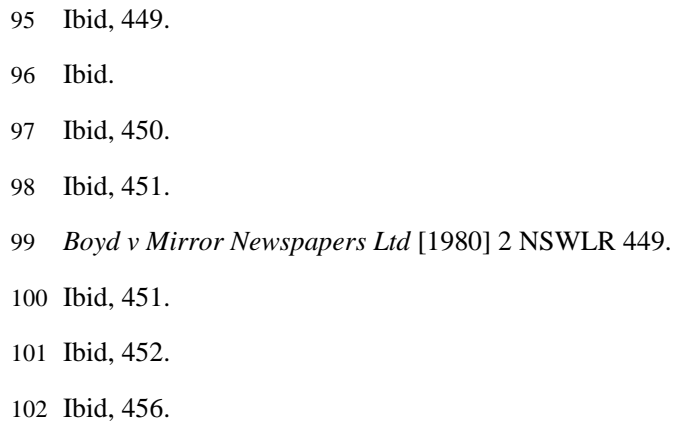


In relation to the second imputation, Hunt $\mathrm{J}$ stated that the word "ridiculous" means deserved to be laughed at, or absurd with Boyd referring to the comments in the article that he had "waddled" onto the field. His Honour stated that it was "open to the ordinary reasonable reader of this article to read into it a suggestion of fault on the part of the plaintiff [Boyd]". This imputation was therefore to go to the jury. ${ }^{103}$ With regard to the third imputation that Boyd had so allowed his physical condition to degenerate that he was a hopeless second row forward in first grade rugby league, Justice Hunt stated that "the imputation of unfitness is not defamatory, unless there is some disparagement of him which lowers his reputation in the judgment of his fellow men". ${ }^{104}$ This third imputation was therefore also held to be a matter for the jury. ${ }^{105}$

Henderson $v$ Thompson and Boyd v Mirror Newspapers involved the media, in the form of newspapers, making criticisms of a player and a competitor. It is suggested the cases indicate that in both Australia and New Zealand it is going to be difficult for a player or competitor to successfully argue that such criticism is defamatory as they are unlikely to result in the player being shunned or avoided. It is also likely that it is either the truth or fair comment, given the fact that it in invariably involves a sports journalist just doing their job. However, in both cases it was held that an imputation of unfitness can be defamatory, but only where it "is shown to have arisen by reason of lack of skill, experience, honesty or industry on the part of the plaintiff."106

Media criticism in the printed medium can also involve comments about the performance of officials in sport and the situation in Hall $v$ Gould involved printed words as well as the spoken words that have already been discussed. Gould had written an article entitled "Smith decision just plain wrong" which appeared in The Sun Herald on 19 August 2001, three days after his radio comments. The subsequent pleaded imputations were similar to those relating to the comments made on the radio, namely that the members of the Panel had conspired together to find Smith guilty, and that the panel had acted disgracefully in finding him guilty. ${ }^{107}$ In regards to the conspiracy imputation, Levine J held that while "a view could be formed that this is a "borderline" capacity question" it was one that should still go to the jury. ${ }^{108}$ The other imputation from the

103 Ibid, 453.

104 Ibid, 454.

105 Ibid, 456.

106 Henderson v Thompson [1934] NZLR 444, 448; Boyd v Mirror Newspapers [1980] 2 NSWLR 449

107 Hall $v$ Gould, para 5. It should be noted that since the content of the spoken and written comments were essentially the same, Hall $v$ Gould illustrates the benefit of having slander and libel combined under the general tort of defamation under the present legislation in both Australia and New Zealand.

108 Ibid, para 25. 
article, namely that the Panel had acted disgracefully was, as a matter of an "overall impression gained by reading the matter complained of", capable of being carried and of being defamatory. ${ }^{109}$

It should be noted that the tort of defamation can also occur when someone effects the reputation of another person by means of photographs or other visual images, and sport has also had cases involving communications involving such images.

\section{SPORT, DEFAMATION AND VISUAL IMAGES}

Not only are a lot of comments made on a daily basis about sport, but a lot of images are also produced, both as action or general shots of sportspersons for use in newspapers and magazines, or for advertisements. Since people can also be defamed by visual images, it is not surprising that there have been a number of defamation cases involving photographs and other images of sportspersons, with the best known of these being Ettingshausen v Australian Consolidated Press. ${ }^{110}$

Andrew Ettingshausen was an Australian rugby league player who had been selected in the Australian team for the 1990 tour to England. After a test match against Great Britain a photograph was taken that depicted Ettingshausen and two other Australian players showering after the game. It was subsequently published in HQ magazine. While the black and white photograph was grainy, it still depicted a shape between the Ettingshausen's legs that was capable of being interpreted as his penis. Shadows and the way the photograph was cropped ensured that the other two players, Ben Ellias and Laurie Daley, did not suffer the same embarrassment. Ettingshausen subsequently sued for defamation, with the imputation being that (a) he had deliberately permitted a photograph to have been taken of him with his genitals exposed for the purposes of reproduction in a publication with a widespread readership; and (b) the plaintiff is a person whose genitals have been exposed to the readers of the defendant's magazine 'HQ', a publication with a widespread readership. ${ }^{111}$

In regard to the first imputation, Hunt $\mathrm{J}$ was of the opinion that the photograph did not suggest that Ettingshausen was in any way aware the photograph was being taken, nor did the way in which he stood suggest a pose. While the caption that accompanied the photograph indicated an intention on the part of the author to show Ettingshausen naked in the showers, there was no suggestion that he was aware of this intention. ${ }^{112}$ His Honour then held that persons of reasonable intelligence may differ as to whether the first imputation would have been conveyed to the ordinary reasonable reader, and was therefore an issue for the jury. ${ }^{113}$

109 Ibid, para 27.

110 Ettingshausen v Australian Consolidated Press [1991] 23 NSWLR 443.

111 Ibid, 445.

112 Ibid, 446.

113 Ibid, 447. 
In regard to the second imputation, Hunt J stated that: ${ }^{114}$

Upon the assumption that the ordinary reasonable reader did not conclude that the plaintiff deliberately permitted the photograph to be taken of him with his genitals exposed for reproduction with a widespread readership ... the publication of this imputation is in my view capable of subjecting the entirely blameless plaintiff to more than a trivial degree of ridicule. ... Accordingly, the imputation is capable of defaming the plaintiff.

When examining the second imputation, Hunt $\mathrm{J}$ applied the principle discussed in Burton $v$ Crowell Pub Co. ${ }^{115}$ In this case photographs of Burton, a "gentleman steeplechaser" had been used in an advertisement for Camel cigarettes, with the one that was the subject of the defamation claim being taken after a race when he was going to be weighed in. His figure had been distorted in the photograph by the fact that a white girth suspended from the saddle appeared to be attached to Burton and not to the saddle. Judge Hand described the photograph's effect as being "grotesque, monstrous and obscene." 116 His Honour noted that had the picture been deliberately produced, every right minded person would have agreed that Burton had a genuine grievance. It was then held that the effect is the same whether it is deliberate or not, since such a caricature affects a man's reputation and "exposes the sufferer to ridicule and contempt."117 It was therefore actionable as it exposed Burton to more than trivial ridicule and the fact that it did not assume to state a fact or an opinion was irrelevant. In regard to the fact that Burton had consented to the use of a photograph for which he posed as an advertisement, this was not consent to the use of the offending photograph as he had no reason to anticipate that the lens would distort his appearance in such a way. ${ }^{118}$

Another 'accidental' publication of a photograph was made by The West Australian newspaper involving one taken of Fremantle's Paul Hasleby during an Australian Football League (AFL) match. This photograph inadvertently displayed part of Hasleby's penis which could be seen under his shorts when he was being tackled. An out of court settlement was made, with The West Australian also running an apology in the paper a few days later. While the financial terms of the settlement were confidential, it is known that Hasleby made a donation to a Perth children's health charity. ${ }^{119}$ What this outcome indicates is that it was not a question of money for Hasleby, just an acknowledgment that his privacy had been invaded, even if it may only have been because the

114 Ibid, 449.

115 Burton v Crowell Pub Co (1936) 82 F 2d 154.

116 Ibid, 154.

117 Ibid, 155.

118 Ibid, 156.

119 Scott Coghlan "Hasleby Reaches Settlement" (17 May 2005) The Weekend Australian 48. 
offending nature of the photograph had not been noticed by the editors of the paper. However, as was held in Burton v Crowell Pub Co, it does not matter if the publication is deliberate or not.

A New Zealand case involving a claim that a visual depiction was defamatory was Mount Cook Group Ltd $v$ Johnstone Motors Ltd. ${ }^{120}$ The visual image in this case was a $48 \mathrm{~cm}$ by $64 \mathrm{~cm}$ poster depicting a bridal couple walking along a gravel path, with the bride's dress being held up and the groom's hand on her bottom in "an overtly sexual gesture."121 There was then a caption on the bottom right hand corner of the poster which read "Please darling no children yet - fun first let's ski Coronet Peak Queenstown." ${ }^{122}$ The poster was displayed and sold at a store known as Queenstown Sports which was owned by Johnstone Motors. The Mount Cook Group had long been associated with Coronet Peak, arguably the most important tourist and recreational attraction in the Queenstown area. ${ }^{123}$ When it became aware of the poster, requests were made to stop the displaying and distribution of the poster, but Johnstone Motors refused to withdraw it from sale or display. ${ }^{124}$ The Mount Cook Group then made a claim for defamation. ${ }^{125}$

Tipping J stated the evidence established that there were a substantial number of people who knew the Mount Cook Group had owned and operated the Coronet Peak ski field for many years. ${ }^{126}$ His Honour then held that ordinary sensible readers with that knowledge would conclude from these circumstances it was either a poster published by the Mount Cook Group, or produced by someone with its approval. The Mount Cook Group had therefore established that the poster had been published, and that it concerned itself. ${ }^{127}$ It was then a question of whether the poster was defamatory. ${ }^{128}$ Tipping $\mathrm{J}$ stated that this required establishing "that ordinary people of reasonable intelligence, seeing the poster and making the link with Mount Cook, would tend to think less of Mount Cook from the point of view of its commercial ethics and standards." ${ }^{129}$ His Honour then

120 Mount Cook Group Ltd v Johnstone Motors Ltd [1990] 2 NZLR 489 (HC) Tipping J.

121 Ibid, 490

122 Ibid.

123 Ibid, 491. This therefore is arguably more of a 'recreational' case than a 'sports' case but it is suggested that the principles are applicable to a sports situation and as is mentioned further on in this article, the sports case of Tolley v J S Fry \& Sons Ltd [1931] AC 333 was extensively referred to.

124 Mt Cook Group Ltd v Johnstone Motors Ltd, above n 120, 494.

125 Ibid, 490. Note that it was also claimed that it constituted passing off and that it represented misleading and deceptive conduct under the Fair Trading Act 1986 (NZ).

126 Ibid, 495.

127 Ibid, 496.

128 Ibid.

129 Ibid, 497. 
held that the poster was "capable of having that effect on the ordinary sensible reader." 130 An injunction was therefore granted preventing Johnstone Motors from publishing the poster, with damages of $\$ 1000$ also being awarded. ${ }^{131}$

In Mount Cook Group Ltd v Johnstone Motors Ltd the English case of Tolley v J S Fry \& Sons $L t d^{132}$ was extensively referred to, Tipping $\mathrm{J}$ stated certain comments made by Viscount Dunedin had a "distinct analogy with the present case."133 The imputation involved a pictorial representation in the form of a cartoon caricature of a leading amateur golfer which had been used in an advertisement for Fry's Chocolates. Tolley claimed that the depiction of him was defamatory as it was an imputation on his amateur status since it suggested that he had been involved in the advertisement for reward, and that this had an impact on his amateur status, with this being held to be capable of a defamatory meaning. ${ }^{134}$

The use of visual images of those involved in sport therefore raises the issue as to when such a use amounts to a defamatory imputation because it lowers the opinion others may have of that individual, or company. These cases clearly indicate that they can be defamatory, and even if a general consent has been given to have photographs taken, this may not extend to the photograph that was actually used in an advertisement.

\section{SPORT, DEFAMATION AND THE MEDIA}

Most modern day sports did not develop their individual rules that give each sport their distinctive character until the mid to late nineteenth century and even well into the twentieth century there was hardly any interaction between sport and the law. However, the first defamation legislation to apply in New Zealand was the Libel Act 1792 (UK) while in Australia, until the enactment of the recent uniform defamation acts, it was acts like the Defamation Act 1889 (Qld) and

130 Ibid.

131 Ibid, 503. Note that under the uniform defamation acts a corporation in Australia has no cause of action for defamation in relation to the publication of defamatory matter about the corporation. However, in relation to the publication of material about the corporation in Mount Cook Group Ltd v Johnstone Motors Ltd it was more to do with linking matter to the company that was the problem which would suggest it lies outside the restrictions present in the Australian acts. See for example Defamation Act 2005, s 9 (NSW), and note that under s 9(2) corporations formed not for financial gain, or one that employs less than 10 people, and is not related to another corporation, are excluded from not having a cause of action for defamation in relation to the publication of defamatory matter about the corporation. Under s 6 of the Defamation Act 1992 defamation proceedings brought by body corporates are considered to have failed unless it has caused pecuniary loss, but there is no restriction on a cause of action for companies as there is under the Australian uniform defamation acts.

132 Tolley v J S Fry \& Sons Ltd [1931] AC 333.

133 Mt Cook Group Ltd v Johnstone Motors Ltd, 499.

134 Tolley v J S Fry \& Sons Ld [1931] AC 333, 342. 
the common law that were in operation. Thus, like many other areas of law, the law of defamation had been well established long before the courts were required to apply it to a sporting context.

Defamation law developed to protect people from imputations that would lower their reputation amongst the general public. It is therefore a significant area of law for sport, given the fact that sport is very much in the public eye through extensive media coverage. What the recent sports related defamation cases indicate is that it is more likely to be officials who take offence to written or spoken statements regarding their performance. A suggested reason for this is that comments attacking the integrity and performance of an official is more likely to be considered defamatory, first of all by the potential plaintiff, and then by the courts, than comments made regarding a player's performance. In both Hall $v$ Gould and the Bellamy case it was the integrity of the NRL judiciary that was challenged while in Coates $v$ Harbour Radio it was the performance, and therefore integrity, of Australia's highest ranked Olympic official that was attacked. Like any citizens, Coates and the judiciary panel were entitled to protect their reputation and in Coates' case, given Alan Jones' power within the media, legal action for defamation was the only practical way to protect his reputation

Another feature of the Bellamy case was that it can be considered to be an "internal sport" case in the sense that both parties were involved in the respective sport and there was no external factor, namely the media. While such cases are not very common, the law of defamation can clearly consider comments made between such people as potentially defamatory. Anderson $v$ Ginn, likewise, was an internal sports case and while the comments in that case were of a personal nature, internal sport comments about someone's competence may also be considered defamatory. The Bellamy case also illustrates that an apology may well be acceptable and while the apology eventually made by Bellamy was considered by the judiciary panel to have been made too late, an incident in AFL several years earlier illustrates how such an apology can defuse the situation and prevent potential litigation.

Essendon's James Hird, one of the AFL's all-time greats, made comments in the media regarding the performance of umpire Scott McLaren which strongly suggested that McLaren did not give Essendon a fair go and that he did not know where McLaren was coming from. These comments were heard live on television by several hundred thousand viewers, with many more hearing them in the subsequent media coverage of the incident. The AFL immediately fined Hird \$20,000, with McLaren also making it clear legal action could be taken if no apology was made. Hird then made a public statement retracting the comments, with the incident being further defused by McLaren publicly thanking Hird for the apology at the beginning of an AFL match. As well as illustrating that an immediate and genuine apology can be all that is required to restore someone's reputation, it also shows the potential role of the media. One of the requirements for a defamatory statement is that it must be published with the media often being the method by which potentially defamatory statements in sport are published, but sport's high media profile also means it can be the medium through which an apology can be made. 
However, an examination of the known sports related defamation cases in Australia and New Zealand indicates that usually the media will have a more direct involvement than just providing the means by which internal sports comments can be published. This can involve visual images in advertisements which have used an image of a sportsperson that distorts the person to a point of ridicule, or lowers the reputation of the person in some other way, such as being made to look like a professional rather than an amateur golfer. While inferring that an amateur golfer is a professional is unlikely to be considered defamatory today, ${ }^{135}$ it should be noted that former Australian Olympic swimming champion, Kieran Perkins, took legal action after Telstra's use of his image in an advertising campaign. Perkins was successful on the basis of passing off, but it had been a type of advertisement that lowered his reputation by association with that company then it could also have been considered defamatory. ${ }^{136}$ Mount Cook Group Ltd v Johnstone Motors Ltd, meanwhile, illustrates that advertisements can defame a sport or recreation based company if it lowers its reputation in the commercial world. The common theme to these situations is the lack of consent for the use of the images, so in regard to the use of visual images in sports related advertisements, consent should be obtained, not just a general consent to take photographs, but consent to the actual image that was used.

Visual images in the form of photographs were also the issue in Ettingshausen $v$ Australian Consolidated Press, and the out of court settlement involving Hasleby and The West Australian. While these two examples show that newspapers and magazines need to be careful when publishing photographs of sportspersons, the way the situations were handled illustrate the potential difference between the involvement of the "sports media" and the "non-sports media." In Ettingshausen $v$ Australian Consolidated Press the article containing the offending photograph was written by someone described by the judge as being "a cappuccino-drinking copywriter from Paddington who had never watched a game of rugby league in his life." ${ }^{137}$ The significance of this is that, being a non-sport journalist, he did not have to worry about the consequences of publishing the photograph. It was a one-off story and the journalist concerned did not need to maintain the respect of Ettingshausen, or the general rugby league community, in order to maintain the contacts required to do his job effectively. If, however, it had been a sports journalist specialising in rugby league who was involved then the career consequences could have been far more serious.

135 To put the Tolley case into perspective it should be noted that during the 1930s professional golfers were considered to be no more than tradespersons and, for instance, were not allowed into the clubhouse. There is the story of one of the leading United States professionals at this time who come over for the British Open and asked an official on arriving at the course whether he could get changed in the clubhouse. He was bluntly told he was not even allowed in the clubhouse, to which the professional replied that it was not a problem as he could get changed in his Rolls Royce!

136 Talmax Pty Ltd v Telstra Corp Ltd (1996) 36 IPR 46 (SC Qld-CA).

137 Ettingshausen v Australian Consolidated Press, above n 110, 446. 
The image of Hasleby, on the other hand, did involve the sports media, and The West Australian acted quickly to diffuse the situation. While there was a genuine sincerity in regard to the apology made by the newspaper there was also an element of self preservation since, if the matter had been taken further, the newspaper would have found itself in conflict with not only Hasleby, but also his club and the Western Australian football community. This reflects the symbiotic relationship between sport and the media: sport needs the media, but the media also needs sport. Another relevant factor was that Ettingshausen $v$ Australian Consolidated Press had set a precedent that would clearly have supported Hasleby in any defamation claim.

The settlement with The West Australian was not the end of the matter for Hasleby, however, as the image was subsequently displayed on the Channel Ten programme, The Panel, with Hasleby then threatening legal action against Channel Ten. ${ }^{138}$ This again illustrates the difference between the sports and the non-sports media. The publication of the photograph in The West Australian was most likely done inadvertently, with the settlement outcome involving an apology and what amounted to a donation to charity indicating that Hasleby had accepted this. Therefore, while this would not have been a defence to a defamation claim, it did prevent Hasleby from commencing legal proceedings. With its subsequent publication on The Panel, however, there was nothing inadvertent about it and it was arguably worse for Hasleby since it involved Australian wide circulation through the television medium, rather than publication by a state based newspaper. The potential non-legal consequences for the programme itself, however, were not the same as it could have been for the newspaper, since it did not rely on contacts within the sporting community for its content.

This differential between dealing with the sports and non-sports media is further illustrated in Coates $v$ Harbour Radio Pty Ltd. While Jones may have been a former Australian rugby union coach and at the relevant time, Deputy Chairman of the Australian Sports Commission, his actual radio programme was a general affairs type programme, not a specialist sports programme. Again it is suggested that he therefore did not have to think of the consequences for his own media career when making his criticisms of the Robbins affair.

Comments made by sports journalists can still lead to claims of defamation, as illustrated by Henderson $v$ Thompson, Boyd v Mirror Newspapers and Hall $v$ Gould. Of the three, Hall $v$ Gould would be the least likely to have an adverse affect on the journalist's career due the fact that it involved criticism of a judiciary panel, rather than players or coaches who may then choose not to deal with that journalist. ${ }^{139}$ Thus, media comments and criticisms made by those specialising in sport are less likely to be of a defamatory nature due to an internal control, namely the journalist's

138 Scott Coghlan "Hasleby reaches settlement" (17 May 2005) The Weekend Australian 48. The author is unaware of the eventual outcome of the situation with Channel Ten.

139 Note that Phil Gould is still writing for The Sun-Herald and working on radio and television. 
need to retain the respect of those involved in the industry. However, the non-sports media is less likely to be as careful, either when a journalist does a one off story, as in Ettingshausen v Australian Consolidated Press, or when the matter becomes big enough to become a feature news story, not just a sports story, as illustrated by Coates $v$ Harbour Radio Pty Ltd. Henderson $v$ Thompson and Boyd $v$ Mirror Newspapers, meanwhile, indicate that criticisms of players by journalists will probably be much harder to successfully argue as constituting defamation than criticisms levelled at officials.

\section{CONCLUSION}

It is suggested that an overview of the sports related defamation cases in Australia and New Zealand indicates that they fall into three main categories:

(1) Those involving internal sports comments.

(2) Those involving the sports media.

(3) Those involving the non-sports media.

The Bellamy case involving internal sports comments has already received considerable media attention, one that is set to continue with the judiciary panel pursuing legal action against Bellamy and the Melbourne Storm. It is suggested, however, that, from a sports perspective, the case signifies a mere storm drifting by, rather than being a case that alters the way sport operates. This is because it is unlikely that the case will see an avalanche of sports related defamation cases in regard to the internal criticisms that regularly occur in sport.

Sport and the media, meanwhile, share a mutual, interdependent relationship. Media rights provide an important direct form of income for professional sport with its coverage also influencing gate receipts and sponsorship. In return, sport helps to sell a lot of newspapers and pay television subscriptions. It is therefore in the interests of both groups that defamation claims be kept to a minimum. However, there will be times when individuals involved in sport have both the need, and the right, to defend their reputations in court from comments made by people in the media with cases, such as Coates $v$ Harbour Radio, indicating that this is more likely to involve the non-sports media.

Sports related defamation cases may be relatively rare, but in an industry where comments and criticisms are frequently made it is still an important area of law in the sporting context, and as the last few years have indicated, cases will reach the courts from time to time. 